\title{
CAN HYPOCRISY BE A VIRTUE? HUME ON THE MORALITY OF PRINCES
}

\author{
HUME E A VIRTUDE DA HIPOCRISIA
}

\author{
Alexandra Abranches* \\ alexandra@ilch.uminho.pt
}

\begin{abstract}
This paper examines the moral status of hypocrisy in the moral and political philosophy of David Hume. Its aim will be to try to determine whether, according to Hume, hypocrisy has any positive moral value, or whether, not having any, Hume should therefore be placed in the same category of political realists such as Machiavelli, with his sharp distinction between moral and political values. If the latter is the case, then hypocrisy can be described as an absolute moral vice. But if the former is the case, that is, if hypocrisy has any moral value, then Hume does not support the sharp separation between what is right from a political and from a moral point of view, which means that there may even be, then, some relation between hypocrisy and moral obligation. In other words, hypocrisy may very well be virtuous.
\end{abstract}

Keywords: Hume, Machiavelli, benevolence, justice, History, human nature, virtue, vice.

Sumário. Examina-se aqui a filosofia moral e política de David Hume para determinar se a hipocrisia tem algum valor moral ou se, pelo contrário, não tem qualquer valor moral. Se este último for o caso, então é plausível colocar Hume na mesma categoria de realistas políticos a que pertencem Maquiavel, Hobbes ou Mandeville. Dada a distinção clara entre valores morais e valores políticos, a hipocrisia seria um vício moral absoluto, fosse qual fosse o seu valor político. Mas se, pelo contrário, se puder mostrar que a hipocrisia tem algum valor moral, então, não fazendo Hume a separação estrita que o realismo político exige entre o moral e o político, poderá existir uma relação entre hipocrisia e obrigação moral e, consequentemente, a hipocrisia será um vício apenas relativo ou, dito de outro modo, poderá ser virtuosa.

Palavras-chave: Hume, Maquiavel, benevolência, justiça, História, natureza humana, virtude, vício. 
"(...) the world is still too young to fix many general truths in politics, which will remain true to the latest posterity. We have not as yet had experience of three thousand years; so that not only the art of reasoning is still imperfect in this science as in all others, but we even want sufficient materials upon which we can reason." "Of Civil Liberty" (1741)1

There is something about hypocrisy that makes it a particularly vicious character trait ${ }^{2}$. The hypocrite is someone who deceives others about what he truly believes, desires and values, who presents a false image of himself and his intentions. This deception is, moreover, deliberate, which explains why we attach such strong moral blame to it and also the revulsion it provokes. It is seen as a substantial moral defect, since the hypocrite not only lies about himself, but he wants to have the advantages that morality furnishes without being himself moral. He pretends to be moral in order to manipulate the system of morality to his advantage. He is to blame both for deceiving others and for believing that it is good or permitted to deceive and manipulate others. His is, therefore, an absolute moral vice.

Still, there could be an argument to the effect that the viciousness of hypocrisy is not absolute. In fact, that argument has been made throughout the history of political philosophy. Venerable thinkers such as Thucydides, Machiavelli, Hobbes, or Mandeville, have defended the idea that hypocrisy is necessary in the public domain and that it is therefore justified. This political

\footnotetext{
${ }^{1}$ References to Hume's works include the following abbreviations: Hume's A Treatise of Human Nature is cited with notations of the form T j.k.m.n / SBN pqr, the lower-case letters here standing for arabic numerals. Numerals immediately following T indicate book, part, section, and paragraph numbers in (Hume, A Treatise of Human Nature, 2005); numerals following 'SBN' indicate page numbers in (Hume, A Treatise of Human Nature, 1969). Hume's Enquiry concerning the Principles of Morals and Enquiry concerning Human Understanding are cited similarly. EPM followed by two numbers gives the chapter and paragraph in (Hume, An Enquiry concerning the Principles of Morals, 1998). EHU followed by two numbers gives the chapter and paragraph in (Hume, An Enquiry Concerning Human Understanding, 2007). And in each case numbers paired with these, following 'SBN', indicate the corresponding page in (Hume, Enquiries Concerning Human Understanding and Concerning the Principles of Morals, 1975). References to Hume's essays shall be given to individual essays in (Hume, Essays: Moral, Political and Literary, 1985) followed by page numbers. In all quotations, emphasis is original unless otherwise indicated.

${ }^{2}$ As Judith Shklar writes in her book Ordinary Vices "hypocrisy remains the only unforgivable sin, perhaps especially among those who can overlook and explain almost every other vice, even cruelty” (Shklar, 1984, p. 45).
} 
realist defence of hypocrisy might, however, be interpreted as spelling out its manipulative and deceitful character, instead of actually being a defence and even less a justification. After all, it would still be about getting what you want through deceit, but under the guise of a public good of some sort. It would still be an abuse of morality in which morality would be treated as a manipulative means to an end the hypocrite might be hard pressed to unveil were he, the hypocrite, to be unveiled as a hypocrite. How can we, after all, trust the hypocrite and believe in his good intentions? The public good seems to require transparency. Hypocrisy is, by its very own nature, irredeemable, a vice even while presenting itself as a virtue precisely because it consists of presenting itself as a virtue.

The political realist would not be discouraged by considerations such as these, though. His is a pragmatic stance. There are times when it really is necessary to deceive in the interest of the public good. When those times arrive, one must not be squeamish. Necessity, and not justification, is what they affirm.

Our concern here will be not with the realist defence of hypocrisy, but with whether there is a case when hypocrisy might be considered a virtue. Hume's thought about hypocrisy, and his moral and political philosophy, may give us some help to determine whether hypocrisy's viciousness might be relative and not absolute.

\section{The limits of self-interest}

Hume devotes a lengthy appendix in his An Enquiry Concerning the Principles of Morals to a refutation of self-love and the hypocrisy that accompanies self-love. In that appendix, he writes that:

THERE is a principle ... that all benevolence is mere hypocrisy, friendship a cheat, public spirit a farce, fidelity a snare to procure trust and confidence; and that while all of us, at bottom, pursue only our private interest, we wear these fair disguises, in order to put others off their guard, and expose them the more to our wiles and machinations (EPM, App. 2.1; SBN 295) (My emphasis).

This principle, he writes, resembles another "which has been much insisted on by philosophers, and has been the foundation of many a system; that, whatever affection one may feel, or imagine he feels for others, no passion is, or can be disinterested; that the most generous friendship, however sincere, is a modification of self-love; and that, even unknown to ourselves, we seek only 
our own gratification, while we appear the most deeply engaged in schemes for the liberty and happiness of mankind" (EPM App.2.2; SBN 296) (My emphasis).

These principles seem to make of us all, and always, hypocrites, no matter what the circumstances might be. In the first case, Hume is describing a principle according to which we are hypocrites in a moral sense, worthy of reproach and blame, to the extent that we wear "fair disguises", which means it is our conscious intentions that are vicious, that we do on purpose wish to appear as something we are not so as to achieve some hidden end. We hide both our intention to deceive and the end we seek by deceiving. We manipulate others in order to benefit ourselves. We use them for our own self-interest.

The second principle is saying that we are not aware of what our real motivations are, of the causes of our actions, which means hypocrisy could be interpreted as neither a vice nor a virtue, but as a fact about our nature. Behind the experience of love or friendship lies self-love. Sincerity is unmasked by the philosopher as deceit. Nature is the hypocrite, not the individual persons whose feelings and actions it motivates. And Nature, as a system of facts, is morally indifferent.

The two principles are, then, quite different. For it is one thing to say that all men are selfish manipulators, and that they are so knowingly. It is another thing to say that all men are selfish manipulators, but they are so unknowingly. Still, both affirm self-interest as the ultimate motivation for human conduct.

One of Hume's arguments against the "selfish system of morals" that these principles represent, a system defended by thinkers such as Hobbes or Locke, who, in these respect, are "superficial reasoners", is that it is a bad theory of human behaviour. It is a reductionist theory, 3 and to such an extent that it ends up being a simplistic theory. 4 And, what is more, it is a simplistic theory which demands very complex turns of thought in order to reduce the phenomena to that

\footnotetext{
3 "An epicurean or a Hobbist readily allows, that there is such a thing as a friendship in the world, without hypocrisy or disguise; though he may attempt, by a philosophical chymistry, to resolve the elements of this passion, if I may so speak, into those of another, and explain every affection to be self-love, twisted and moulded, by a particular turn of imagination, into a variety of appearances" (EPM App.II.4; SBN 249-50).

4 "All attempts of this kind have hitherto proved fruitless, and seem to have proceeded entirely from that love of simplicity which has been the source of much false reasoning in philosophy” (EPM App. II.6; SBN 298).
} 
simplistic explanation. 5 Hume writes that "[T] the most obvious objection to the selfish hypothesis is, that, as it is contrary to common feeling and our most unprejudiced notions, there is required the highest stretch of philosophy to establish so extraordinary a paradox" (EPM, App. 2.6; SBN 298).

And then, there are the numerous examples in nature of general benevolence which make it simpler to explain human behaviour "from the combined motives of benevolence and self-enjoyments ...” (EPM, App.2.13; SBN 302).

Hume identifies benevolence as a second principle in human nature besides self-interest. This identification of benevolence as a second source of motivation for human behaviour and as a second source of feeling and experience provides an explanation for common phenomena which doesn't call for an excess of theory. Facts make the selfish system too costly to uphold. Too much mental energy has to be spent in speculative explanations if one is to do it. And for someone who wants to do for the science of human nature what Newton did for the science of nature, facts should not be overrun by hypothesis, however simple and elegant in their simplicity they might seem. The fact that benevolence is also a motivation for human behaviour means that we are not all and always deceivers, be it in the sense described by the first of the two principles mentioned above, be it in the sense described by the second of those principles. We can be sincere in our benevolent actions, when we profess friendship, when we exhibit public spirit, when we make promises and affirm our fidelity. Nature does not compel us to pursue only our self-interest and to be, therefore, incapable of being disinterested. We must not all, and always, be hypocrites.

\section{Benevolence and justice}

Benevolence, then, is one of the main motives behind human behaviour. So is self-interest, of course, but the fact that benevolence is an independent factor means that not all behaviour can be reduced to self-interest. And this in turn means that not all benevolent acts are, of necessity, self-interest in disguise.

\footnotetext{
5 "When a philosopher, in the explication of his system, is obliged to have recourse to some very intricate and refined reflections, and to suppose them essential to the production of any passion or emotion, we have reason to be extremely on our guard against so fallacious an hypothesis" (EPM App. II; SBN 299).
} 
Even though we are not egoists, in Hume's speculative history of human association self-interest plays the major role. Benevolence, the natural virtue, is both too short in its reach and too weak to provide the proper resources and materials with which to build a civil society. The history of civil society is the history of self-interest pitted against itself, and from this struggle emerges justice, the artificial virtue which keeps humans under the authority of impartial and very often harsh rules. Benevolence, the natural virtue, is also a social virtue, but its scope hardly goes beyond family and friends, and its strength diminishes as its scope is enlarged. It shows that human existence has always been social and sociable, and it shows that there are sources of feeling and behaviour in human nature beyond self-interest, but it doesn't guarantee that sociability will prevail over competition. What makes benevolence a social virtue is the fact that it contributes to general happiness by being useful and/or agreeable to oneself and/or to others. With each benevolent action, and with each action expressing some derivative form of benevolence, such as delicacy or generosity, general happiness is enhanced. It shows that humans are not lonely, independent individuals roaming the landscape and getting into scrapes with other individuals, but it doesn't say human nature is all benevolence and no hostility.

Benevolence and justice, both social virtues, one natural the other artificial, have each a distinctive way of contributing to the common good. While benevolence is practiced in individual actions, justice is a system and application of general rules. This difference means that the two virtues can and often do come into conflict with one another. And when this happens, justice has the upper hand, which may contribute to its image of stern coldness, of indifference to personal suffering. Hunger, destitution, illness might well be considered, from a benevolent point of view, reasons to ignore or bend the rules that protect private property, for instance. But justice has not been born out of benevolence, its origin lies in the fight against the self-destructive effects of unbridled self-interest. From the point of view of justice, each action must be treated in the same way. Exceptions, even if justified by benevolence, put at risk the whole system of laws 
that keeps in check that other, and very powerful, human motivation, selfishness. ${ }^{6}$

\section{The general point of view}

In a footnote to the Enquiry Concerning the Principles of Morals, Hume writes:

It is wisely ordained by nature, that private connexions should commonly prevail over universal views and considerations; otherwise our affections and actions would be dissipated and lost, for want of a proper limited object. Thus a small benefit done to ourselves, or our near friends, excites more lively sentiments of love and approbation than a great benefit done to a distant commonwealth: But still we know here, as in all the senses, to correct these inequalities by reflection, and retain a general standard of vice and virtue, founded chiefly on general usefulness (EPM, 5.42 n25; SBN 229 n1).

People commonly do not live up to what morality requires of them, but it is a good thing that they do not. The apology Hume offers on behalf of humankind is stated in the observation that nature ordained this wisely. Nature did not just ordain it, but it did so wisely. Human psychology explains this wisdom of nature: proximity and definition of the objects under consideration "excite more lively sentiments", which otherwise would be “dissipated and lost”. Still, this doesn't mean nature is against considerations of general usefulness. Nature is the basis upon which we have been building a general standard of vice and virtue. And even if we are not Ideal Spectators, we are capable of reflection7, and so of correcting and enlarging our point of view towards general usefulness. Benevolence's narrow scope and short reach represent a moral benefit, since they give us an object that excites our sentiments, that is, they are motivationally powerful; but they also represent a moral deficit, since they are a new way of practicing egoism. It is justice, with its demand for a general and disinterested point of view that gradually corrects the "inequalities" of feeling we have for those who are near -

\footnotetext{
${ }^{6}$ Hume has a very illuminating metaphor for the difference between the two social virtues: "The happiness and prosperity of mankind, arising from the social virtue of benevolence and its subdivisions, may be compared to a wall, built by many hands, which still rises by each stone that is heaped upon it, and receives increase proportional to the diligence and care of each workman. The same happiness, raised by the social virtue of justice and its subdivisions, may be compared to the building of a vault, where each individual stone would, of itself, fall to the ground; nor is the whole fabric supported but by the mutual assistance and combination of its corresponding parts" (EPM App. 3. 5; SBN 305).

7 "as in all the senses": we also correct the external senses by reflection; they may deceive us, we resort to the testimony of others, to experience, to probability, in order to correct the information they give us, and to be "[T] the wise man [who] proportions his belief to the evidence." EHU 10.1
} 
and for the nearest one of all, our selves - and those who are far. By inspiring feelings such as civic virtue and honesty, of which the sensible knave described by Hume in the second Enquiry is incapable, justice ensures the possibility of political society.

The virtue of Justice brings objectivity into the human scene. To make a proper objective judgment founded on proper sentiments, to give reasons which other people can be expected to understand, we have to adopt an impersonal stance. Either we adopt the point of view of the Impartial Spectator, the point of view of humanity, the impersonal point of view, or we don't. And if we don't, we are no longer giving moral reasons for our judgments. As Hume writes:

\begin{abstract}
When a man denominates another his enemy, his rival, his antagonist, his adversary, he is understood to speak the language of self-love, and to express sentiments, peculiar to himself, and arising from his particular circumstances and situation. But when he bestows on any man the epithets of vicious or odious or depraved, he then speaks another language, and expresses sentiments, in which he expects all his audience are to concur with him. He must here, therefore, depart from his private and particular situation, and must choose a point of view, common to him with others; he must move some universal principle of the human frame, and touch a string to which all mankind have an accord and symphony. If he mean, therefore, to express that this man possesses qualities, whose tendency is pernicious to society, he has chosen this common point of view, and has touched the principle of humanity, in which every man, in some degree, concurs (EPM 9.10; SBN 272) (My emphasis).
\end{abstract}

Hume's criticism of self-interest and his theory of justice as impartiality apparently steer him in the direction of the condemnation of hypocrisy as an absolute vice. But there is a topic in Hume's writings where his less rigorous views about hypocrisy are manifested. In his opinion on the phenomenon of politeness, which he develops in his Essays, he presents hypocrisy as the condition of civilization. His defence of "manners" comes very close to a defence of hypocrisy when he writes that "among the ancients, there was not much delicacy of breeding, or that polite deference and respect, which civility obliges us either to express or counterfeit towards the persons with whom we converse" (My emphasis) (Hume, 1985a, pp. 111-137).

The ancients were too rough by being too straightforward. Hume is, in fact, one of the main figures of the eighteenth century "culture of politeness" 8 that

\footnotetext{
${ }^{8}$ An expression used by Lawrence Klein (Klein, 1994).
} 
would be accused by the "culture of sincerity" of hiding privilege and injustice under the romantic cover of civility and chivalry. 9

\section{The morality of princes}

Another test on the limits of morality is politics, the actual behaviour of princes and governments. Machiavelli, a thinker who in The Prince represents political realism at its strongest, argues for a separation between morality and politics. This separation means that that which is called hypocrisy is simply a necessary act in order to preserve power or the common good. One might call it hypocrisy from the point of view of morality. But from the point of view of politics there is no sense in calling it that because the political realm is not the place to make moral judgments. Politics and morality have different values. You choose one or the other and judgments made from one and the other do not necessarily coincide. In Chapter 15 of The Prince, Machiavelli writes that “... it is necessary to a prince, if he wants to maintain himself, to learn to be able not to be good, and to use this and not use it according to necessity."10

Necessity is dictated by the way the world is, including human nature as part of that world. Acting according to virtue in the world is ruinous, given that most men are not virtuous ${ }^{11}$. Morality, in fact, has not gained root in this world, except as part of perception: people "consider" virtues to be good and vices to be bad,

\footnotetext{
${ }^{9}$ In Mary Wollstonecraft's A Vindication of the Rights of Men, for instance, this attack reaches considerable proportions, with Burke, another representative of this defense of custom, being lambasted for his deference to power, and denounced as a self-serving hypocrite. Wollstonecraft writes that behind Burke's professions of concern for liberty lie his "tyrannical principles", that his cry for the birthrights of Englishmen does not refer to that birthright which all men have but only to those that some men happen to have. "Security of property", writes Wollstonecraft, "is the definition of English Liberty". Hume's conception of justice includes protection of property at its core, so this definition suits it very well. And the revolution Wollstonecraft is defending in her attack on Burke is also a form of political action Hume would find both foolish and destructive. In his 'Idea of a Perfect Commonwealth' (Hume, 1985b, pp. 512-529) Hume rejects utopian plans that would destroy the present order and make a fresh start. Society, he believes, is a complex mechanism that has been and is being built throughout human history, and its screws and planks and springs have been tested by experience. Sometimes they get rusty or damaged, but they can be fixed, replaced even. Through gradual change, reform and progress are made possible. Still, this anti-revolutionary point of view is not necessarily a form of hypocrisy. It can be, when it resists those changes that would bring down unjustified privileges or abhorrent forms of oppression under the guise of something else, as Wollstonecraft's criticism of Burke says he is doing. But being an advocate of reform is compatible with perfect sincerity, as the example of John Stuart Mill should make clear.

${ }^{10}$ (Machiavelli, 1998)

11 "for it is so far from how one lives to how one should live that he who lets go of what is done for what should be done learns his ruin rather than his preservation. For a man who wants to make a profession of good in all regards must come to ruin among so many who are not good" (Machiavelli, 1998, Ch. 15).
} 
and they consider some actions to be vicious and others to be virtuous; and the prince has to be "so prudent as to know how to avoid the infamy of those vices that would take his state from him and to be on guard against those that do not, if that is possible; but if one cannot, one can let them go on with less hesitation"12 (My emphasis).

Virtue and vice may look like virtue and vice yet reveal themselves to be the exact opposite if we measure them against the standard of politics, which is success, success in bringing "security and prosperity" to the state. And this means that there will never "be wanting to a prince legitimate reasons to excuse this nonobservance" 13 of treaties or promises made to other princes.

Hume seems to share some ideas with Machiavelli that would make it plausible to put them in the same category of political realists: the rejection of utopian views in Machiavelli's The Prince and in Hume's 'The Idea of a Perfect Commonwealth' points in that direction; and so does the fact that both dedicate themselves to the study of History instead of designing an abstract theory of how the state should be.

But Hume's stance on the relation between morality and politics is also based on a complex theory of human nature, and on the speculative, but still naturalistic, history that gradually evolves society out of the universal human passions of pleasure and pain. Hume claims he is not speculating but doing empirical science. And certainly he does not pretend to be doing normative theory. But Hume also has a substantive theory of human nature from which he has extracted a rule that, insofar as it contributes to the general good, should be adopted as a standard of behaviour and judgment. That rule states that "every quality which is useful or agreeable to ourselves or others" should be called a virtue, and the contrary a vice. Usefulness and agreeableness could be accompanied with a metric, but Hume doesn't say how we might be able to

\footnotetext{
12 "And further more one should not care about incurring the fame of those vices without which it is difficult to save ones' state; for $\mathrm{i}$ f one considers everything well, one will find to be virtue, which if pursued would be ones' ruin, and something else appears to be vice, which if pursued results in one's security and well-being" (Machiavelli, 1998, Ch. 15).

13 "And if all men were good, this teaching would not be good; but because they are wicked and do not observe faith with you, you also do not have to observe it with them. Nor does a prince ever lack legitimate causes to color his failure to observe faith" (Machiavelli, 1998, Ch. 18).
} 
measure them, just as he is vague about what utility consists in. But what is important in this rule is that it is not a set list of do's and don'ts, a catalogue of virtues and vices. It is, rather, a rule that determines why qualities are virtues or vices and also when ${ }^{14}$ qualities are virtues or vices. And when properly applied, this rule may demand significant changes in our catalogue of virtues and vices:

Celibacy, fasting, penance, mortification, self-denial, humility, silence, solitude, and the whole train of monkish virtues; for what reason are they everywhere rejected by men of sense, but because they serve to no manner of purpose; neither advance a man's fortune in the world, nor render him a more valuable member of society; neither qualify him for the entertainment of company, nor increase his power of selfenjoyment? We observe, on the contrary, that they cross all these desirable ends; stupify the understanding and harden the heart, obscure the fancy and sour the temper. We justly, therefore, transfer them to the opposite column, and place them in the catalogue of vices; nor has any superstition force sufficient among men of the world, to pervert entirely these natural sentiments. A gloomy, hair-brained enthusiast, after his death, may have a place in the calendar; but will scarcely ever be admitted, when alive, into intimacy and society, except by those who are as delirious and dismal as himself (EPM 9.3; SBN 270).

Hume is, then, very much on the side of morality and on the side of its reformation, and he is one of those who, like Rousseau and many others in the eighteenth century, defended Machiavelli from the charge of Machiavellism, of teaching ruthless amorality or even immorality. ${ }^{15}$ In the essay 'Of the Study of History', Machiavelli is even given as the example of the impartiality, that intellectual and moral virtue, of historians, who “... have been, almost without exception, the true friends of virtue, and have always represented it in its proper colours" (Hume, 1985c, pp. 563-68).

Hume considers that the study of History is part of the science of human nature inasmuch as it "extends our experience to all past ages, and to the most distant nations; making them contribute as much to our improvement in wisdom, as if they had actually lain under our observation" (Hume, 1985c, pp. 563-68). There is no contradiction or detachment in his work as a philosopher and as an historian. Through History, the past becomes part of the experience philosophy has to refer to, to learn about human nature.

\footnotetext{
${ }^{14}$ See the example of chastity in T 3.2.12.

15 "MACHIAVEL himself discovers a true sentiment of virtue in his history of FLORENCE. When he talks as a Politician, in his general reasonings, he considers poisoning, assassination and perjury, as lawful arts of power; but when he speaks as an Historian, in his particular narrations, he shows so keen an indignation against vice, and so warm an approbation of virtue, in many passages, that I could not forbear applying to him that remark of HORACE, That if you chace away nature, tho' with ever so great indignity, she will always return upon you" (Hume, 1985c, pp. 563-68).
} 
But this doesn't mean that the historian is subservient to the philosopher. And according to Hume, historians are better than philosophers in an important way. Unlike philosophers, historians look directly at agency and agents. A historian is "sufficiently interested in the characters and events, to have a lively sentiment of blame or praise". She has a closer view of the moral dimensions of actual life being lived by actual individuals, and so she has a more lively sense of what it means to be virtuous or vicious. History is the scene in which vice and virtue unfold. And this is why the study of History is recommended by Hume as a source of moral learning for the public at large. History is not merely a collection of facts. Hume connects the study of particular historical events with his study of human nature, which includes the social virtues of benevolence and justice. And he attributes to History an important role for instruction on private and public virtue not only for philosophers but for the general reading public.

In the second Enquiry, he writes that "History, experience, reason sufficiently instruct us in this natural progress of human sentiments, and in the gradual enlargement of our regards to justice, in proportion as we become acquainted with the extensive utility of that virtue" (EPM 3.1; SBN 192). Utility, or usefulness, as we saw above, is what makes any virtue a virtue, and justice is no exception. In other words, where justice is not useful then it must be abandoned. Perfect benevolence or complete abundance, for instance, makes justice useless, so does the extreme need for self-preservation in civil war or disaster. In stable societies, respect for property, fidelity to promises, obedience to laws, are moral obligations. But they cease to be so in times of emergency or in the land of milk and honey.

But justice isn't only a domestic virtue. The Law of Nations is the name of the new set of rules and duties which arise from the intercourse between different states ${ }^{16}$. As far as we are talking of law, and rules, and duties, we are talking about

\footnotetext{
16 "When civil government has been established over the greatest part of mankind, and different societies have been formed contiguous to each other, there arises a new set of duties among the neighbouring states, suitable to the nature of that commerce, which they carry on with each other" (T 3.11; SBN 376). "When a number of political societies are erected, and maintain a great intercourse together, a new set of rules are immediately discovered to be useful in that particular situation; and accordingly take place under the title of Laws of Nations. Of this kind are, the sacredness of the person of ambassadors, abstaining from poisoned arms, quarter in war, with others of that kind, which are plainly calculated for the advantage of states and kingdoms in their intercourse with each other" (EPM 4.2; SBN 205).
} 
justice or morality, in this case, international justice. This intercourse between nations is carried out because there is some advantage to the parties involved, and in this sense, relations among states can be compared to the relations among individuals that constitute each political society. The difference is that, Hume writes in the Treatise, "though the intercourse of different states be advantageous, and even sometimes necessary, yet it is nor so necessary nor advantageous as that among individuals, without which it is utterly impossible for human nature ever to subsist"17 (T 3. 2.11; SBN 377).

The utility of the intercourse among nations is not as strong as the utility of the association among individuals. Or, as Hume puts in the second Enquiry, “... here is the difference between kingdoms and individuals. Human nature cannot by any means subsist, without the association of individuals; and that association never could have place, were no regard paid to the laws of equity and justice. Disorder, confusion, the war of all against all, are the necessary consequences of such a licentious conduct. But nations can subsist without intercourse. They may even subsist, in some degree, under a general war" (EPM 4.3; SBN 206).

Because, then, regulated relations among states are less useful than regulated relations among individuals, "the morality of princes ... has not the same force as that of private persons, and may lawfully be transgressed from a more trivial motive"18 (T 3.11; SBN 376) (My emphasis). Hume's position is not that morality and politics are separate realms, but that moral obligations in those two domains have different strengths. Individual agents are bound to the virtues and to justice in such a way that "nothing less than the most extreme necessity, it is confessed, can justify individuals in a breach of promise, or an invasion of the properties of others" (EPM 4; SBN 206). But "we must necessarily give a greater indulgence to a prince or minister, who deceives another; than to a private gentleman, who breaks his word of honour" (T 3.11; SBN 377). And we can "reconcile us more easily to any transgression of justice among princes and republics, than in the private commerce of one subject with another" (T 3.2.11;

\footnotetext{
17 "though the intercourse of different states be advantageous, and even sometimes necessary, yet it is nor so necessary nor advantageous as that among individuals, without which it is utterly impossible for human nature ever to subsist" (T 3.11; SBN 377).

18 "though the intercourse of different states be advantageous, and even sometimes necessary, yet it is nor so necessary nor advantageous as that among individuals, without which it is utterly impossible for human nature ever to subsist” (T 3.11; SBN 377).
} 
SBN 377). Blame and praise are still in order as forms of assessment of the behaviour of princes, who are still objects of moral judgment and causes of moral feeling. But these aren't as strong as those we reserve for our neighbours and fellow citizens.

Justice within the state and between states differs in terms of usefulness, but it is still justice, it is still a form of morality. Transgressions of justice among nations are still violations of moral obligations, but these are proportional to usefulness, so where usefulness is small or non-existent, moral obligation is small or non-existent. If there is some agreement whose usefulness is small, our moral obligation to abide by it is also small, which means that transgressing it is not seriously bad.

What is more, if, as Hume writes, "[T]he observance of justice, though useful among them, is not guarded by so strong a necessity as among individuals; and the moral obligation holds proportion with the usefulness" (EPM 4; SBN 206), then the prince is not morally obligated to keep his promises and being a hypocrite is not morally to blame. And if usefulness is the standard, it may even be the case that, in some individual instances, the prince is morally obligated to be a hypocrite, in case that proves useful to the state.

How, then do we turn a vice (hypocrisy in the private realm) into a sort of virtue (political hypocrisy)? If a virtue is that which satisfies the standard of morality, and if political hypocrisy satisfies the standard of morality, then political hypocrisy is a virtue.

Whereas political realists such as Machiavelli separate politics from morals and make moral judgments insignificant in the political realm, which means that there are no hypocritical princes, just effective or ineffective princes; Hume does not effect this separation, and offers instead a way of making hypocrisy compatible with morality, since "... the moral obligation holds proportion with the usefulness" (EPM 4.3; SBN 206).

So, even though his position seems to be the same as Machiavelli's, as he expressly talks of reasons of state justifying the breach of justice, the fact is that as far as he has utility as a standard of virtue, and as far as he admits that there might be changes in our catalogue of virtues if only we reflect upon those acts and 
qualities of mind which contribute to our common good, one may conclude that hypocrisy, which is an absolute vice in the realm of the relations among individuals, may be a relative virtue, and not merely a breach of justice, in the realm of the relation among nations. This insight might be made more plausible when paired with Hume's defence of politeness as a pillar of civilization, but this theme will not be pursued here.

\section{Conclusion}

Hume's treatment of the theme of the morality of princes and of the relations between the states seems to allow for the idea of a relatively virtuous hypocrisy. While hypocrisy, as a character trait of individuals, is an absolute vice, and individuals are morally obligated to keep faith, and may be legally sanctioned when they don't, hypocrisy as the particular actions of princes in particular circumstances, even though they appear to be breaches of justice, even of that weaker form of justice which is the law of nations, may after all be considered a relative virtue if by virtue what we mean is that action or character trait which is useful. Hume admits that justice itself might cease to be a virtue when circumstances render it useless. Hypocrisy, then, may become a virtue if it becomes useful. When it comes to the relation among individuals, it is in fact a vice because it is in fact harmful to social life. But in the case of relations between states, if it is specifically useful, we may consider it a relative virtue, relative to circumstances and to the weakness of moral obligation in the international sphere.

There is another form of hypocrisy that might draw out the fact of political hypocrisy's relative virtuousness or viciousness: religious hypocrisy. This, indeed, is a form of hypocrisy that deserves being called absolute, that one can say that has no redeeming value whatsoever, because the end it is a means to is false, and because it stirs up violent and destructive passions. As Hume says in a celebrated sentence: "Generally speaking, the errors in religion are dangerous; those in philosophy only ridiculous" (T 1.4. 7; SBN 185).

\section{References}

Hobbes, T. (1996). Leviathan (R. Tuck, Ed.) Cambridge: Cambridge University Press. 
Hume, D. (1969). A Treatise of Human Nature. London: Penguin Books.

Hume, D. (1975). Enquiries Concerning Human Understanding and Concerning the Principles of Morals. Oxford: Oxford University Press.

Hume, D. (1983). The History of England (Vols.1-6). Indianapolis: Liberty Fund.

Hume, D. (1985a). Of the Rise and Progress of the Arts. In Essays: Moral, Political and Literary. Indianapolis: Liberty Fund.

Hume, D. (1985b). The Idea of a Perfect Commonwealth. In Essays: Moral, Political and Literary. Indianapolis: Liberty Fund.

Hume, D. (1985c). Of the Study of History. In Essays: Moral, Political and Literary. Indianapolis: Liberty Fund.

Hume, D. (1998). An Enquiry Concerning the Principles of Morals. Oxford: Oxford University Press.

Hume, D. (2005). A Treatise of Human Nature. Oxford: Oxford University Press.

Hume, D. (2007). An Enquiry Concerning Human Understanding. New York: Oxford University Press.

Klein, L. (1994). Shaftesbury and the Culture of Politeness . Cambridge: Cambridge University Press.

Machiavelli, N. (1998). The Prince. Chicago and London: The University of Chicago Press.

Mandeville, B. (1997). The Fable of the Bees and Other Writings. Indianapolis: Hacket.

Shklar, J. (1984). Ordinary Vices. Cambridge, MA: Belknap Press of Harvard University Press.

Wollstonecraft, M. (1995). A Vindication of the Rights of Men and $A$ Vindication of the Rights of Woman. Cambridge: Cambridge University Press. 